\title{
Investigation of the Seasonal Variations in the Solar Radiation Balance and Other Solar Energy Parameters in Some Cities in Nigeria
}

\author{
ISIKWUE, B. C. ${ }^{1}$, Akiishi, M. ${ }^{1} \&$ Utah, E. U. ${ }^{2}$ \\ ${ }^{1}$ Department of Physics, Federal University of Agriculture Makurdi, Benue State, Nigeria \\ ${ }^{2}$ Department of Physics, University of Uyo, Uyo, Nigeria \\ Correspondence: ISIKWUE, B. C., Department of Physics, Federal University of Agriculture Makurdi, Benue \\ State, Nigeria. Tel: 234-803-501-2663. E-mail: bcisikwue@gmail.com
}

Received: June 14, 2014 Accepted: July 7, 2014 Online Published: July 9, 2014

doi:10.5539/esr.v3n2p59 URL: http://dx.doi.org/10.5539/esr.v3n2p59

\begin{abstract}
An investigation of the variations of the Solar Radiation Balance, SRB, and other solar energy parameters in some cities in Nigeria has been carried out in this work. The data used for the study were obtained from the Nigerian Meteorological Agency (NIMET) Abuja, (1990-2010). The results show that the maximum range of atmospheric albedo, ALB, between $56-64 \%$ was obtained in the rainy season; with the minimum range of about $33-39 \%$ occurring in the dry season. Direct relationship existed between the SRB and other investigated solar radiation parameters, each of which in turn varied indirectly with the ALB. Relatively high annual values in SRB in Port Harcourt and Makurdi, implies that these locations are suitable for solar energy applications including farming. And devices using solar energy applications in these areas could function efficiently during the dry season.
\end{abstract}

Keywords: Solar Radiation Balance, Solar Radiation, net solar radiation, net terrestrial radiation, albedo, Port Harcourt, Makurdi, and Kano

\section{Introduction}

The Sun provides the principal energy that drives the climate system. Hence, climatic variability is partly due to changes in solar radiation distribution, which in turn is caused by some natural and anthropological phenomena. The solar energy is emitted in all directions, with only a small fraction being in the direction of the Earth, because part of this radiation is scattered and reflected back to space mainly from clouds, air molecules and other atmospheric constituents. The remaining energy, which is absorbed heats up the atmosphere and gets re-emitted as terrestrial radiation. The amount of solar energy incident on the atmosphere determines the weather and climate system.

The difference between the absorbed solar radiation and the emitted radiation from the Earth's surface is known as the solar radiation balance, SRB (Liou, 1980). A positive solar radiation balance implies more incoming solar radiation, which warms the Earth system, while negative solar radiation balance implies more emission of terrestrial radiation, which causes cooling in the Earth system (Chacko et al., 1998). Knowledge of the SRB of the Earth's atmosphere improves the understanding of the climate (Ezenekwe et al., 2013).

Due to its proximity to the Atlantic Ocean in the South and to the Sahara Desert in the North, Nigeria experiences some variations in the climate system. This is due to the fact that the moisture laden from the Atlantic Ocean brings with rainy season, which often affects the climate in the southern part, while the dust laden air mass from the Sahara Desert causes extreme hotness to the areas in the northern part of the country. Thus, the variations caused by these temperature regimes cause imbalance in the radiation budget of the country. Consequently, extreme weather conditions are unavoidable. Therefore, the investigation into radiation balance of the atmosphere provides information necessary for climatic prediction.

Several researches have been carried out on the estimation and utilization of solar radiation as well as on the evaluation of solar radiation energy balance in Nigeria (Isikwue et al., 2014; Ezenenekwe et al., 2013; Isikwue et al., 2012a, b and c; Ogolo et al., 2009; Babatunde et al., 2005 and so on). This present work is a step further in the earlier investigation of radiation energy balance in some selected cities in Nigeria (Isikwue et al., 2014). But here, we look at seasonal variations of solar energy radiation balance in Port Harcourt, Makurdi and Kano in 
Nigeria. This study in the seasonal behavior of the SRB will provide more detailed information on the climatic effect of the solar energy radiation balance as suggested in the earlier paper. The reasons for choosing these cities are as provided in the earlier paper.

The daily global solar radiation, minimum temperature and maximum temperature data used in this work were obtained from the Nigeria Meteorological Agency (NIMET) Abuja - Nigeria (1990 - 2010). The solar radiation parameters considered in this work are the global solar radiation denoted by SR, the net solar radiation (NSR), the reflection coefficient or albedo denoted by ALB, the net terrestrial radiation (NTR) and the solar radiation balance (SRB)

\section{Methods of Analysis}

The NSR $\left(\mathrm{MJm}^{-2}\right.$ day $\left.^{-1}\right)$ was determined using the equation given by FAO (1998) as

$$
\text { NSR }=R_{s}\left(1-\alpha_{s}\right)
$$

$R_{s}$ is the global solar radiation, $\alpha_{s}$ is the ALB of the location obtained from Babatunde et al. (2005) as

$$
\alpha_{\mathrm{s}}=\frac{\mathrm{H}_{\mathrm{r}}}{\mathrm{R}_{\mathrm{a}}}
$$

and the $H_{r}$ is the reflected radiation given as

$$
\mathrm{H}_{\mathrm{r}}=\left(1-\frac{\mathrm{R}_{\mathrm{S}}}{\mathrm{R}_{\mathrm{a}}}\right) \mathrm{R}_{\mathrm{a}}
$$

The $\frac{R_{S}}{R_{a}}$ is the clear sky index, where $R_{a}$ is the extraterrestrial radiation obtained using the expression given by Duffie and Beckman (1991) and was employed by Isikwue et al. (2012a) as:

$$
R_{a}=\frac{24}{\pi} I_{s} d_{r}\left[w_{s} \sin \theta \sin \delta+\cos \theta \cos \delta \sin w_{s}\right]
$$

where $I_{S}$ is the solar constant $\left(4.92 \mathrm{MJm}^{-2} \mathrm{day}^{-1}\right)$ and $\theta$ is the latitude of the location expressed in radians. The solar declination angle, $\delta$ is given in radians and by the expression

$$
\delta=23.45 \sin \left[\frac{360}{365}(J+284)\right]
$$

The $\mathrm{J}$ is the Julian day of the year and $w_{s}$ is known as the sun set angle given by Isikwue et al. (2012c) as

$$
w_{s}=\cos ^{-1}(-\tan \theta \tan \delta)
$$

The $d_{r}$ is eccentricity correction factor of the Earth's orbit which according to Allen et al. (1998) was given as

$$
d_{r}=1+0.033 \cos \left(\frac{360 J}{365}\right)
$$

Furthermore, NTR was obtained using the expression (FOA, 1998):

$$
\mathrm{NTR}=\mathrm{S}\left[\frac{\mathrm{T}^{4} \max +\mathrm{T}^{4}{ }_{\min }}{2}\right]\left(0.34-0.14 \sqrt{\mathrm{e}_{\mathrm{a}}}\right)\left(1.35 \times \frac{\mathrm{R}_{\mathrm{S}}}{\mathrm{R}_{\mathrm{so}}}-0.35\right)
$$

$\mathrm{T}_{\max }, \mathrm{T}_{\min }$, are respectively the maximum and minimum absolute temperatures during 24 hour period; and $\mathrm{S}$ is the Stefan Boltzmann's constant $\left(4.903 \times 10^{-9} M J K^{-4} m^{-2} d a y^{-1}\right)$. The actual vapour pressure, $\mathrm{e}_{\mathrm{a}}$, was computed using the relation adapted from Slaviša and Svetlana (2009) as:

$$
e_{a}=0.611 \exp \left[\frac{17.27 T_{\min }}{T_{\min }+273.3}\right]
$$

On the other hand, the clear sky solar radiation $\left(\mathrm{MJm}^{-2} \mathrm{day}^{-1}\right), \mathrm{R}_{\mathrm{so}}$, which is the solar radiation that would reach the surface under cloudless condition was obtained using the relation given by Allen et al. (1998) as

$$
\mathrm{R}_{\text {so }}=\left(0.75+2 \times 10^{-5} \times \mathrm{Z}\right) \mathrm{R}_{\mathrm{a}}
$$

where $\mathrm{Z}$ is the elevation of the station with respect to sea level (m). For Port Harcourt, Makurdi and Kano, the values for $Z$ are about $468,106.4$ and 479 m respectively. 
Finally, the SRB of the Earth's atmosphere, which is the difference between the NSR and the NTR, was determined using the expression

$$
R B=(1)-(6)
$$

\section{Results}

Tables 1-3 present the monthly mean solar radiation parameters in Port Harcourt, Makurdi and Kano stations respectively, while the annual mean variations of the solar radiation parameters in the three stations over the period (1990-2010) are given in Table 4. On the other hand, Figures 1-5 illustrate respectively the profiles of mean monthly Albedo (ALB), Solar Radiation (SR) also known as the global solar radiation, Net Solar Radiation (NSR), Net Terrestrial Radiation (NTR) and Solar Radiation Balance (SRB) in Port Harcourt (PH), Makurdi (MKD) and Kano (KNO).

Table 1. Monthly mean Solar Radiation parameters in Port Harcourt

\begin{tabular}{cccccc}
\hline Months & ALB & $\begin{array}{c}\mathrm{SR} \\
\left(\mathrm{MJm}^{-2} \mathrm{day}^{-1}\right)\end{array}$ & $\begin{array}{c}\mathrm{NSR} \\
\left(\mathrm{MJm}^{-2} \mathrm{day}^{-1}\right)\end{array}$ & $\begin{array}{c}\mathrm{NTR} \\
\left(\mathrm{MJm}^{-2} \mathrm{day}^{-1}\right)\end{array}$ & $\begin{array}{c}\text { SRB } \\
\left(\mathrm{MJm}^{-2} \mathrm{day}^{-1}\right)\end{array}$ \\
\hline Jan & 0.419 & 17.205 & 11.014 & 2.561 & 8.561 \\
Feb & 0.474 & 17.524 & 9.894 & 2.153 & 7.859 \\
Mar & 0.519 & 17.819 & 8.992 & 1.707 & 7.313 \\
Apr & 0.564 & 17.290 & 8.095 & 1.288 & 6.753 \\
May & 0.562 & 17.667 & 8.400 & 1.266 & 7.048 \\
Jun & 0.517 & 19.400 & 10.003 & 1.605 & 8.304 \\
Jul & 0.507 & 19.752 & 10.152 & 1.734 & 8.368 \\
Aug & 0.532 & 18.595 & 9.048 & 1.559 & 7.440 \\
Sep & 0.487 & 19.429 & 10.436 & 1.851 & 8.492 \\
Oct & 0.480 & 17.900 & 10.081 & 1.897 & 8.077 \\
Nov & 0.440 & 17.043 & 10.594 & 2.169 & 8.281 \\
Dec & 0.394 & 17.262 & 11.918 & 2.629 & 9.264 \\
\hline
\end{tabular}

Table 2. Monthly mean Solar Radiation parameters in Makurdi

\begin{tabular}{cccccc}
\hline Months & ALB & $\begin{array}{c}\text { SR } \\
\left(\mathrm{MJm}^{-2} \mathrm{day}^{-1}\right)\end{array}$ & $\begin{array}{c}\mathrm{NSR} \\
\left(\mathrm{MJm}^{-2} \mathrm{day}^{-1}\right)\end{array}$ & $\begin{array}{c}\mathrm{NTR} \\
\left(\mathrm{MJm}^{-2} \mathrm{day}^{-1}\right)\end{array}$ & $\begin{array}{c}\mathrm{SRB} \\
\left(\mathrm{MJm}^{-2} \mathrm{day}^{-1}\right)\end{array}$ \\
\hline Jan & 0.365 & 18.614 & 12.220 & 3.621 & 8.598 \\
Feb & 0.464 & 16.878 & 10.316 & 2.714 & 7.602 \\
Mar & 0.526 & 17.883 & 9.072 & 2.245 & 6.827 \\
Apr & 0.520 & 19.470 & 9.800 & 1.740 & 8.060 \\
May & 0.528 & 19.674 & 9.559 & 1.893 & 7.667 \\
Jun & 0.537 & 19.071 & 9.242 & 1.663 & 7.579 \\
Jul & 0.543 & 18.650 & 9.042 & 1.619 & 7.423 \\
Aug & 0.559 & 17.633 & 8.462 & 1.425 & 7.037 \\
Sep & 0.562 & 16.551 & 8.242 & 1.414 & 6.228 \\
Oct & 0.478 & 17.839 & 10.264 & 2.001 & 8.263 \\
Nov & 0.391 & 17.996 & 12.105 & 2.761 & 9.343 \\
Dec & 0.352 & 17.812 & 12.244 & 3.686 & 8.558 \\
\hline
\end{tabular}


Table 3. Monthly mean Solar Radiation parameters in Kano

\begin{tabular}{cccccc}
\hline Months & ALB & $\begin{array}{c}\text { SR } \\
\left(\mathrm{MJm}^{-2} \mathrm{day}^{-1}\right)\end{array}$ & $\begin{array}{c}\mathrm{NSR} \\
\left(\mathrm{MJm}^{-2} \mathrm{day}^{-1}\right)\end{array}$ & $\begin{array}{c}\text { NTR } \\
\left(\mathrm{MJm}^{-2} \mathrm{day}^{-1}\right)\end{array}$ & $\begin{array}{c}\text { SRB } \\
\left(\mathrm{MJm}^{-2} \mathrm{day}^{-1}\right)\end{array}$ \\
\hline Jan & 0.331 & 17.060 & 12.228 & 2.964 & 9.265 \\
Feb & 0.383 & 18.986 & 12.379 & 2.631 & 9.748 \\
Mar & 0.464 & 19.595 & 10.825 & 2.044 & 8.782 \\
Apr & 0.537 & 19.195 & 9.180 & 1.507 & 7.673 \\
May & 0.555 & 19.138 & 8.837 & 1.380 & 7.457 \\
Jun & 0.593 & 18.071 & 7.753 & 1.932 & 12.797 \\
Jul & 0.601 & 15.625 & 6.715 & 1.092 & 6.661 \\
Aug & 0.640 & 15.452 & 6.534 & 0.738 & 5.796 \\
Sep & 0.577 & 16.186 & 7.384 & 1.191 & 6.193 \\
Oct & 0.459 & 17.610 & 10.142 & 2.071 & 8.071 \\
Nov & 0.284 & 18.086 & 13.747 & 3.326 & 10.421 \\
Dec & 0.339 & 15.876 & 13.327 & 2.904 & 8.423 \\
\hline
\end{tabular}

Table 4. Annual mean variations of Solar Radiation parameters (1990-2010)

\begin{tabular}{cccccc}
\hline Location & ALB & $\begin{array}{c}\text { SR } \\
\left(\mathrm{MJm}^{-2} \mathrm{day}^{-1}\right)\end{array}$ & $\begin{array}{c}\text { NSR } \\
\left(\mathrm{MJm}^{-2} \mathrm{day}^{-1}\right)\end{array}$ & $\begin{array}{c}\text { NTR } \\
\left(\mathrm{MJm}^{-2} \mathrm{day}^{-1}\right)\end{array}$ & $\begin{array}{c}\text { SRB } \\
\left(\mathrm{MJm}^{-2} \mathrm{day}^{-1}\right)\end{array}$ \\
\hline Port Harcourt & 0.491 & 18.070 & 9.890 & 1.870 & 7.980 \\
Makurdi & 0.485 & 18.170 & 10.050 & 2.250 & 7.820 \\
Kano & 0.480 & 17.570 & 9.750 & 1.980 & 8.44 \\
\hline
\end{tabular}

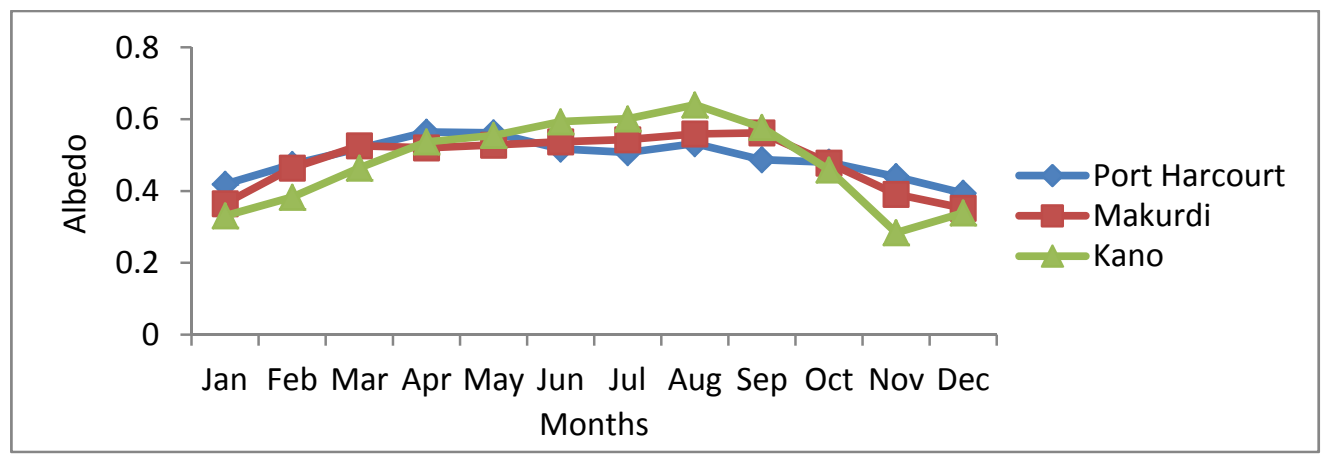

Figure 1. Profiles of monthly mean Albedo in Port Harcourt, Makurdi and Kano

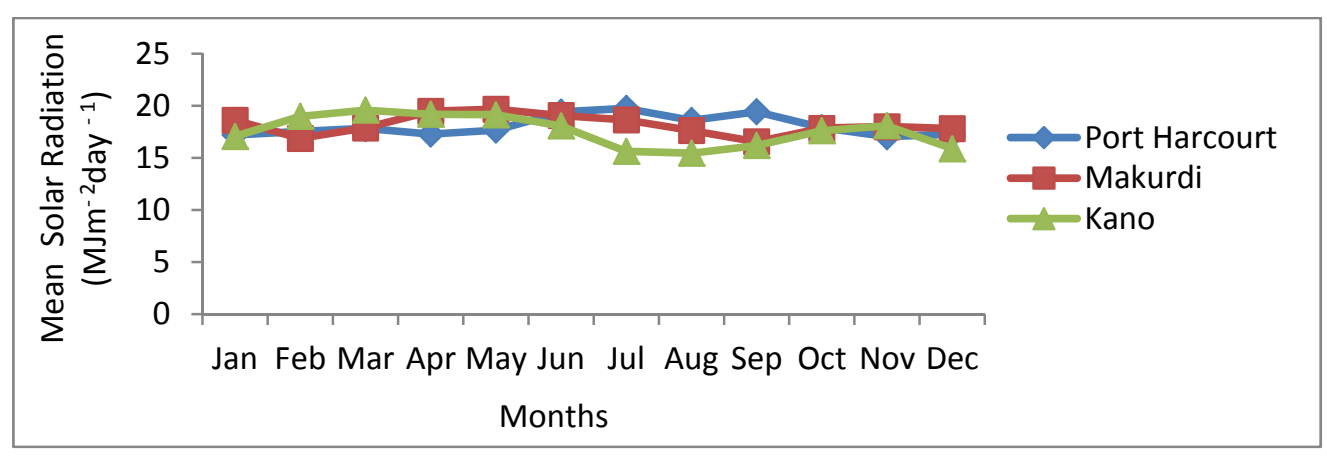

Figure 2. Profiles of mean Solar Radiation in Port Harcourt, Makurdi and Kano 


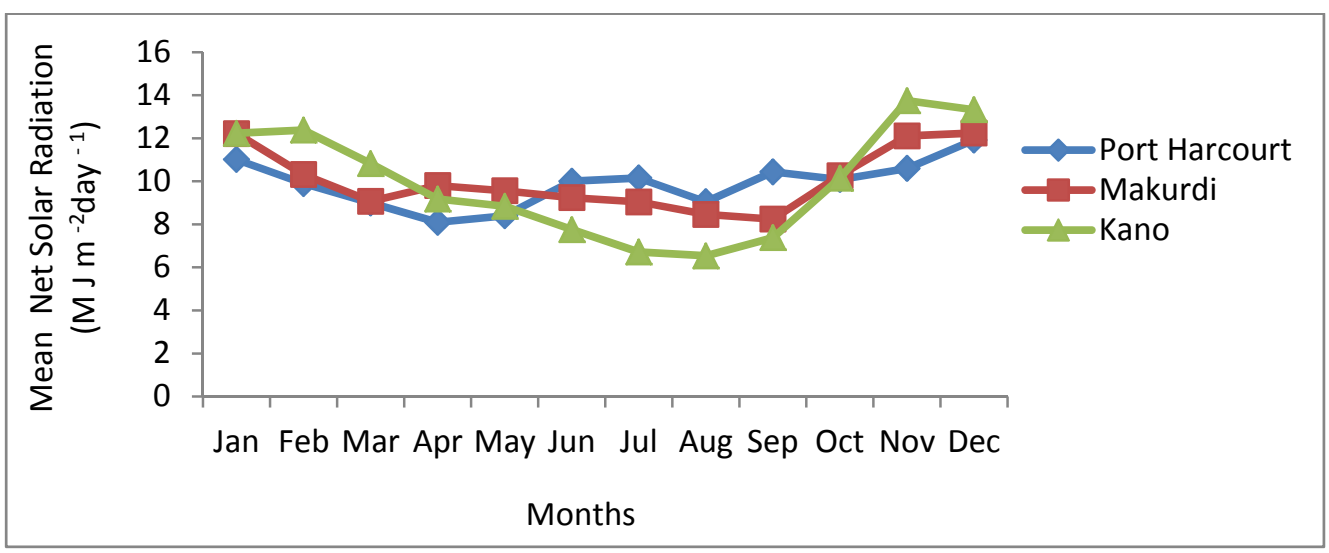

Figure 3. Profiles of mean net Solar Radiation in Port Harcourt, Makurdi and Kano

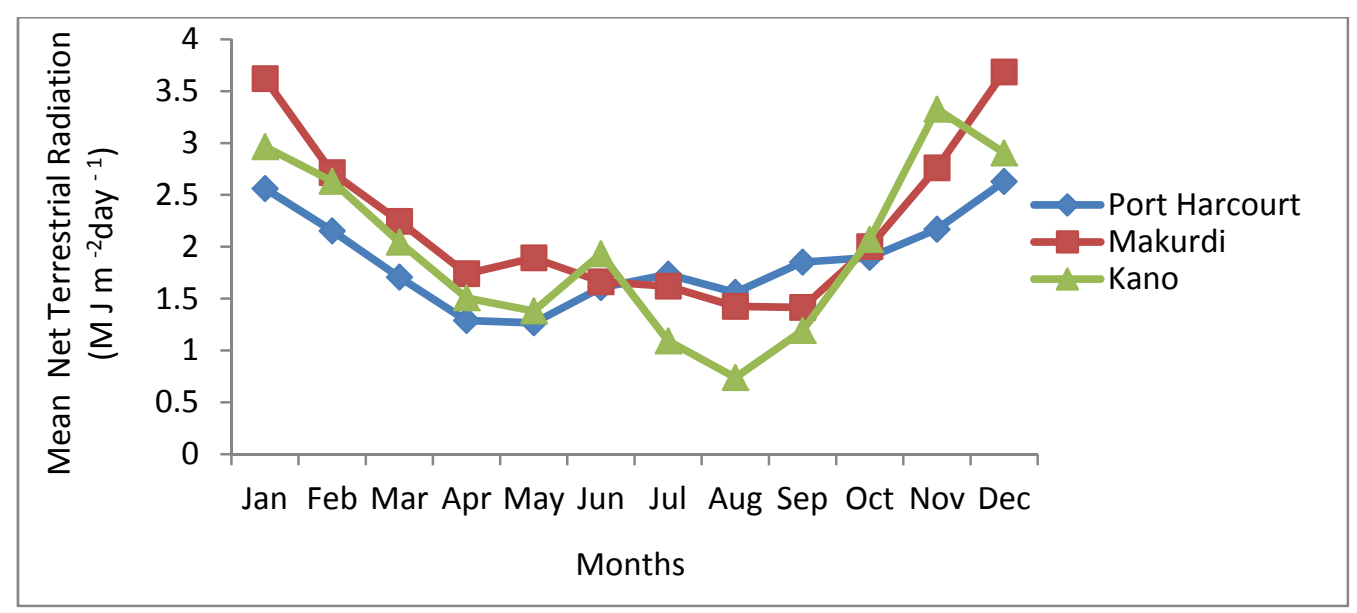

Figure 4. Profiles of mean net Terrestrial Radiation in Port Harcourt, Makurdi and Kano

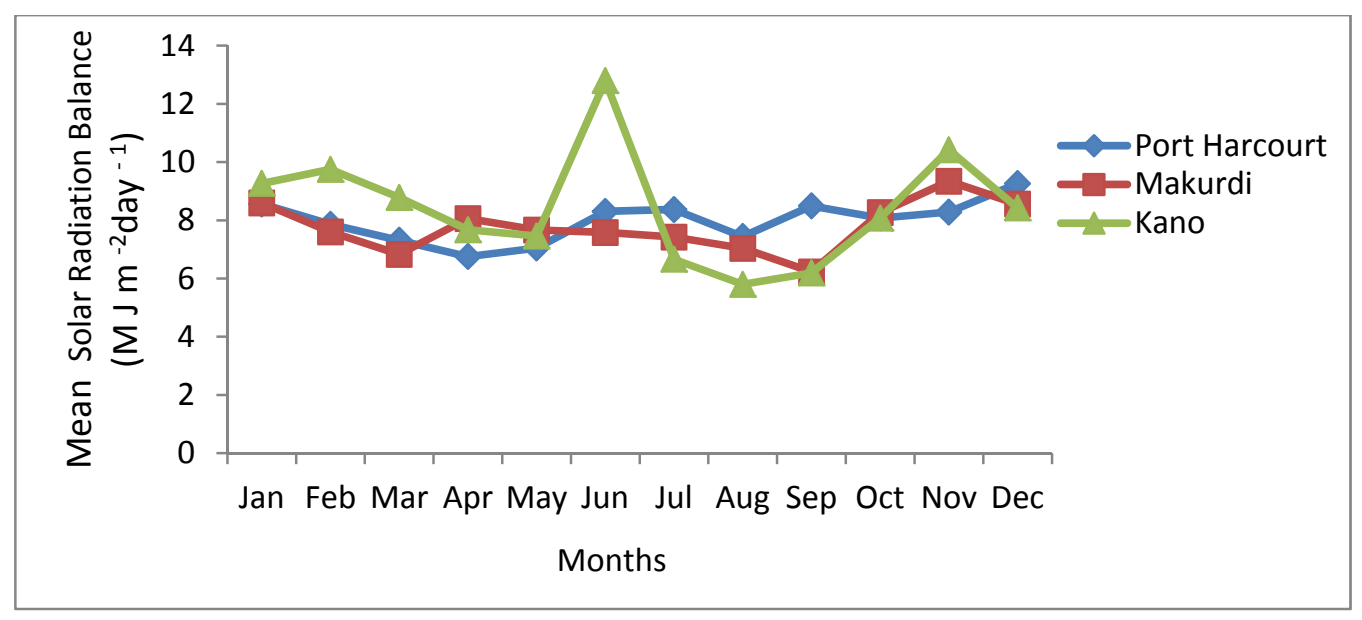

Figure 5. Profiles of mean Solar Radiation Balance in Port Harcourt, Makurdi and Kano

\section{Discussions}

From Tables 1-5 and Figures 1-4, it could be observed that in PH during the period (November-February), the ALB was relatively low with the minimum of about $39 \%$ occurring in the month of December. On the other hand, relatively high ALB was obtained during the period (March-October) with maximum ALB of about $56 \%$ in March and April. In Makurdi, low ALB was observed in November-January with minimum of about $35 \%$ in December. On the other hand, high ALB occurred between February-October with maximum ALB of about 56\% 
in September. For Kano, there was low ALB in November - February with the minimum (33\%) in January. Increase in ALB was observed in March - October with the maximum (64\%) occurring in August.

From these observations, one can say that the maximum amount of about 56-64\% of solar radiation did not reach the surface in the areas under study and within the study period especially in the rainy season. This could be due to the rain bearing clouds which pervaded the sky at that period. This could imply possibility of poor performance of the solar energy systems, particularly solar concentrating devices and low surface temperature during this season since most of the solar radiation is sent back to space by reflection. On the other hand, the minimum amount of solar radiation that did not reach the surface was in the range $33-39 \%$ and occurred mostly in the dry season. This could be attributed to relatively cloudless nature of the sky during the dry season. This agrees with the assertion made by Babatunde et al. (2005) who observed among other things that albedo is generally high during rainy season and low during the dry season.

Among the stations considered, PH experienced the highest annual ALB of about 49\% (Table 4), probably due to its location in the rain forest climatic zone, while Kano had relatively the lowest annual ALB of about 48\%. This could be due to its location the in the Sahel Savannah with mainly grass land and little or no vegetative canopies and rain clouds that could enhance the reflectivity of the solar radiation. This implies that reflection of solar radiation back to space due these factors were minimal in Kano and more solar radiation reached the Earth's surface.

In Port Harcourt, high SR was observed between June - September with maximum (19.732 $\left.\mathrm{MJm}^{-2} \mathrm{day}^{-1}\right)$ in July. However, the minimum SR (17.043 $\mathrm{MJm}^{-2}$ day $^{-1}$ ) occurred in November. However, in Makurdi, high SR was obtained in the period April- June with the maximum SR (16.555 $\mathrm{MJm}^{-2} \mathrm{day}^{-1}$ ) in September. For Kano, high SR was obtained in the period (February - June) with the maximum SR (19.595 $\mathrm{MJm}^{-2} \mathrm{day}^{-1}$ ) in March and minimum of about $\left(15.452 \mathrm{MJm}^{-2} \mathrm{day}^{-1}\right)$ in August. These observations imply that maximum solar radiation of about 19-20 $\mathrm{MJm}^{-2}$ day $^{-1}$ could be obtained between the rain forest and Sahel Savannah climatic zones of Nigeria in the period February - September, whereas low SR of about (15-17 $\left.\mathrm{MJm}^{-2} \mathrm{day}^{-1}\right)$ could be available in the period ( November - January).

Low values of the NSR, particularly in Figure 4 were obtained during the rainy season, probably due to high albedo, which reflects much of the solar radiation back to space, thereby causing much cooling on the Earth's surface. On the other hand, due to reduced albedo during the dry season, the NSR was high causing high SR to be absorbed by the .Earth with a corresponding high surface temperature.

In considering the SRB, for PH, it could be observed from Tables 1-4 and Figures 1-5 that the maximum SRB of about $9.264 \mathrm{MJm}^{-2} \mathrm{day}^{-1}$ corresponds to the minimum ALB of $39.4 \%$ in the month of December, while the minimum SRB of $6.753 \mathrm{MJm}^{-2} \mathrm{day}^{-1}$ corresponds to maximum ALB of $56 \%$ in April. This corresponds to the very low NTR of about.288 $\mathrm{MJm}^{-2} \mathrm{day}^{-1}$. For Makurdi station, maximum SRB of about $9.343 \mathrm{MJm}^{-2} \mathrm{day}^{-1}$ in November corresponds to a low ALB of about $39.1 \%$ in the month of November with high NTR of about 2.761 $\mathrm{MJm}^{-2} \mathrm{day}^{-1}$. But the minimum SRB of about $6.22 \mathrm{MJm}^{-2}$ day $^{-1}$ corresponds to the maximum ALB of about $56.2 \%$ in September. This corresponds with a low NTR of about1.414 $\mathrm{MJm}^{-2} \mathrm{day}^{-1}$. This relationship existing among the ALB, NTR and SRB could also be observed in Kano station. Hence, from these observations, it could be inferred that SRB varies directly with NTR and NSR, but indirectly with ALB.

From the annual values of the parameters (Table 5), it could be observed that the highest annual SRB (7.980 $\mathrm{MJm}^{-2}$ day $^{-1}$ ) is obtained in PortHarcourt irrespective of the high ALB.

Interestingly, among the three locations, Makurdi has the highest annual NSR $\left(10.050 \mathrm{MJm}^{-2} \mathrm{day}^{-1}\right), \mathrm{NTR}(2.250$ $\mathrm{MJm}^{-2}$ day $^{-1}$ ) with high SRB (7.820 $\left.\mathrm{MJm}^{-2} \mathrm{day}^{-1}\right)$. The high NTR could be due to some features such as river Benue that cuts across the city, which absorbs solar radiation. This implies a large amount of infra red radiation being released with a corresponding high temperature (Isikwue et al., 2012a and b; Ramanathan, 1987). With relatively high annual values in SRB, it implies that PH and Makurdi are suitable for solar energy applications including farming. And devices using solar energy applications in these areas could function efficiently during the dry season.

\section{Conclusions}

The following conclusions are drawn from this work:

$>$ The maximum amount of about 56-64\% of solar radiation did not reach the surface in the areas under study and within the study period especially in the rainy season. On the other hand, the minimum amount of solar radiation that did not reach the surface was in the range $33-39 \%$ and occurred mostly in the dry season.

$>$ Among the stations considered, Port Harcourt experienced the highest annual ALB of about $49 \%$. 
$>$ Direct relationship exists among the SRB, NTR and NSR, each of which in turn varies indirectly with ALB.

$>$ A positive radiation balance existed in all the stations under consideration.

$>$ Among the three locations, Makurdi had the highest annual NSR $\left(10.050 \mathrm{MJm}^{-2} \mathrm{day}^{-1}\right), \mathrm{NTR}(2.250$ $\mathrm{MJm}^{-2}$ day $\left.^{-1}\right)$ with high SRB (7.820 $\mathrm{MJm}^{-2}$ day $\left.^{-1}\right)$.

$>$ With relatively high seasonl values in SRB, it implies that PH and Makurdi are suitable for solar energy applications including farming. Consequently, devices using solar energy applications in these areas could function efficiently during the dry season. This is because high SRB implies low ALB which in turn implies more reception of solar energy on the Earth's surface. This could help in plants' photosynthesis and over all solar energy technological applications.

\section{Acknowledgement}

The authors remain thankful to the Nigerian Meteorological Agency Abuja, Nigeria who provided the Dataset used in this work.

\section{References}

Allen, R. G., Pereira, L. S., Raes, D., \& Smith, M. (1998). Crop Evapotranspiration Guidelines for computing crop water requirements. (FAO) Irrigation and Drainage Paper No. 47, Food and Agricultural Organization of United Nations.

Babatunde, E. B., Falaiye, O. A., \& Uhuegbu, C. C. (2005). Simulated reflected SW radiation and its characteristics variation at Ilorin, Nigeria. Nigerian Journal of Physics, 17, 193-201.

Chacko, O., Thomas, C. T., \& Mani, A. S. (1998). Surface Radiation Balance Measurements in India during IQSY. Indian journal of Geophysics, 19, 93-98.

Duffie, J. A., \& Beckman, W. A. (1991). Solar Engineering of Thermal Processes. John Willey and Sons, New York.

Ezenekwe, L. N., Ezemonye, M. N., \& Emeribe, C. N. (2013). Modeling the temporal patterns of short wave and long wave radiations over Sudan and Sahel Savannah. Sacha Journal of Environmental Studies, 3, 34-44.

FAO (Food and Agricultural Organization) (1998). Irrigation and Drainage Paper 56. Italy Rome.

Isikwue, B. C., Amah, A. N., \& Agada, P. O. (2012a). Empirical Model for the Estimation of Global Solar Radiation in Makurdi, Nigeria. Global Journal of Science frontier Research Physics Space Science, 12(1), 58-61.

Isikwue, B. C., Odiaka, C. H., \& Utah, E. U. (2012b). Estimation of the diffuse fraction of Solar Radiation for Makurdi, Nigeria. International Journal of Science and Advanced Technology, 2(2), 1 - 4.

Isikwue, B. C., Audu, M. O., \& Utah, E. U. (2012c). Estimation of the diffuse fraction of solar radiation for Makurdi, Nigeria. International Journal of Science and Advanced Technology, 2(2), 1-10.

Isikwue, B. C., Akiishi, M., \& Utah, E. U. (2014). Investigation of Radiation Energy Balance in some selected cities in Nigeria. IOSR Journal of Applied Physics (IOSR-JAP), 6(2), 21-27. http://dx.doi.org/10.9790/4861-06232127

Liou, K. N. (1980). An introduction to Atmospheric Radiation. New York: Sandiego Academic Press.

Ogolo, E. O., Falodun, S. E., Oluyanmo, S. S., \& Nymhas, E. (2009). Analysis of data on net long wave and Global radiation during a transition period in a tropical station in Southwest Nigeria. Pacific Journal of Science and Technology, 10, 584-591.

Ramanathan, V. (1987). The role of Earth radiation budget studies in climate and general calculations research. Geophysics Research, 92, 475-495.

Slaviša, T., \& Svetlana, Ž. (2009). Effect of actual vapor pressure on estimating evapotranspiration at Serbia. Architecture and Civil Engineering, 7(2), 171-178. http://dx.doi.org/10.2298/FUACE0902171T

\section{Copyrights}

Copyright for this article is retained by the author(s), with first publication rights granted to the journal.

This is an open-access article distributed under the terms and conditions of the Creative Commons Attribution license (http://creativecommons.org/licenses/by/3.0/). 